\title{
Reimbursements of The Application of Google Classroom by University Scholars for Learning Vocational and Entrepreneurship Courses
}

\author{
Amos Ochayi Onojah*, Omotayo Olabo Obielodan, Adekola Musiliu Aderoju, \\ Adenike Aderogba Onojah, Boluwatife Joshua Adigun \\ Department of Educational Technology, University of Ilorin, Nigeria \\ "Correspondence: haymoresonojah@gmail.com
}

Received: 31 July; Accepted: 16 December 2021; Published: 27 December 2021

\begin{abstract}
Google classroom had been used for instructional delivery of courses at all levels of education with tertiary institution inclusive. The use of these technologies had their merits as well as their demerits. This study investigates the reimbursement of Google classroom by undergraduate students for learning vocational and entrepreneurship courses. This study employs the survey method and 250 undergraduate students were purposively sampled. The findings established that Google classroom is very useful for learning vocational and entrepreneurship courses. Gender had no significant influence on the reimbursements of undergraduates' utilization of google classroom for learning vocational and entrepreneur courses but academic level had significant influence. The study concluded that there could be tremendous increase in lecturers job performance as well as students' academic performance if Google classroom is employed for lectures.
\end{abstract}

Keywords: Reimbursements, Application, Google Classroom, University Scholars, Learning Vocational and Entrepreneurship Courses

\section{INTRODUCTION}

Students and instructors both gain from e-learning. E-learning is an alternative to learning that takes place outside of the lecture hall for students, fostering learning independence, assisting in the development of lifelong learning, and enabling students to communicate with one another. While E-Learning has advantages for lecturers, it also modifies teaching techniques, which has an influence on job professionalism, gives chances to analyze and evaluate each student's learning, and allows students to explore themselves more efficiently. Based on the explanation, it can be said that e-learning has a positive impact on lecturers and students, as well as the renewal of teaching and learning. Education was defined by Soetan et al. (2020) as a process of acquiring knowledge through study or imparting knowledge by way of instructions or some other practical procedures. Students with in self-isolation period need more than ability and skills in order to perform successfully, they also need the sense of value to use the technologies well and to regulate their learning. The dreams of change and progress of any nation rely on the capacity of its qualitative education being the most valuable instrument for attaining sustainable development and it's a sure way to various successes of any nation that unlock the divergent opportunities particularly in science and technology (Ala, 2020).

The 21st Century has witnessed the advancement of learning technologies especially in the area of electronic learning. In developed countries, learning has been made easier as a result of easy availability and accessibility to computers, internet service and other electronic devices (Omoni \& Ifeanyichukwu, 2015). Students are, therefore, enthusiastic about the usage of these devices in the learning process as they make use of devices in for their personal and day to day 
activities. The potential of e-learning to allow students to study without the restrictions of time and place, as well as to cut internal training expenses for certain businesses, has contributed to its growing popularity. The internet's availability provides a conduit for the adoption of an electronic approach to education. Simply defined, e-learning is the process of teaching and learning via the use of a computer and an interconnected network. It entails delivering organized educational resources to a student from a repository (Atsumbe et al., 2012).

When teaching and learning activities involving computers and mobile devices are involved, Google Classroom (CC) is necessary (Kumar \& Bervell, 2019). CC has features that aid teacher and student jobs, such as reporting on observation results; asking questions/quizzes online; reviewing literature and other sources of information to assess learners' understanding; planning investigations; analyzing and interpreting data; proposing answers; making predictions; and communicating the results (Nizal, et al., 2018). For students, Google Classroom offers the ability to simplify communication and productivity. Teachers may use Google Classroom to establish an online classroom where they can handle all of the materials that their students require. The papers are saved on Google Drive and may be updated using Google Drive apps like Google Docs and Sheets. It enables teachers to set up an online classroom, invite students, and then create and distribute assignments. Teachers can freely provide scientific assessments and give students with an independent assessment (Wijaya, 2016). Teachers can provide materials on the subject being taught, assign tasks for students, and upload the students' grades so that they can immediately see the scores obtained in the course.

Shittu et al. (2016) discussed the importance of ICT in education, claiming that the growing demand from educational institutions for new teaching innovations demonstrates how trustworthy $\mathrm{ICT}$ is in improving the teaching and learning process. Blended learning is one way to achieve the aim by combining the learning process (e-learning) with traditional lecturing (Nasir, 2018). Blended learning is a learning technique based on the qualities and completeness of the Learning Management System (LMS) into the associated software to support e-learning with a combined approach of lectures and other forms of instruction (Hidayat, 2018). Scholars have previously investigated the effectiveness of e-learning platforms such as Moodle, Google Classroom, and Edmodo (Hakim, 2016), the optimization of Google Classroom as a learning media (Soni, 2018), Google Classroom as an alternative way to improve learning quality (Sewang, 2017), and Google Classroom as a media for Improving Graduate Attributes (Sewang, 2017). This present study will focus on ways in which Google Classroom can be used effectively by undergraduates to learn vocational and entrepreneurship courses in University of llorin.

Over 140 postsecondary schools yearly produce more than 300,000 graduates, ensuring the availability and platform for fundamental economic growth requirements (Otokiti, 2012). However, there are numerous obstacles to Nigeria's socioeconomic growth. According to a report published in 2001 by the National Poverty Eradication Programme (NAPEP), Nigerian universities and other tertiary institutions produce an average of 120,000 graduates each year, while another 500,000 school leavers or college graduates are turned out each year with no hope of finding work (Awogbenle \& Iwuamadi, 2010). Onasanya (2019) emphasized the 21st century's breakthrough in ICT and asserted that the emergence of new edtech trends helps the construction of diverse venues for educational interactions. Higher education institutions can generate future specialists and academics who can adjust to shifting work patterns (Ahmad, 2018). Google Classroom takes web-based services, such as Google Apps for Education, a step further for education by combining them into a single virtual, interactive platform that serves as an online classroom for students (Onojah et al., 2020).

Many capable and highly skilled individuals who have been unable to find meaningful job have remained economically reliant on their parents due to a lack of occupational skills required to be self-employed and operate effectively in the twenty-first century workplace (Osalor, 2014). As a result, Olanipekun, et al. (2015) described the Nigerian educational system in light of 21stcentury reality. They claimed that Nigeria's current situation indicates that the country is operating in a 21st-century economy with a 19th-century educational system. A system in which significant 
emphasis is still put on the traditional classroom setting, with great veneration for certificates for graduates who are, in most cases, taught to be job seekers, as demonstrated by the country's current high unemployment rate. If COVID-19 teaches public health professionals anything, it's that there are now methods available to assist limit an infectious illness before drastic measures such as quarantines and curfews are required (Park, 2020). In all domains, including our educational settings, the use of technology is required. There is a lot of emphasis on incorporating technology into the classroom through new teaching practices that focus on helping students to meet their learning goals (Hwang et al., 2018). However, in the absence of an enabling environment, lecturers may be forced to resort to more traditional methods of education (Ochayi et al, 2021).

Several studies have been done to investigate the influence of gender on student e-learning usage. While some research found that male students react more favourably to e-learning than female students (Liaw \& Huang, 2011), others (Egbo et al., 2011) believed that female students would adopt information and communication technology (ICTs) use more than males. According to Liaw \& Huang (2011), males have a more favourable attitude toward e-Learning than females. Furthermore, the researchers argued that learners' motivation for e-learning is influenced by their computer abilities and experiences. Individual factors such as gender and computing abilities, according to Zabadi \& Al-Alawi (2016), are insufficient. Age, gender, computer experience, technological acceptability, and individual learning styles were all recognized as major factors in affecting students' views toward e-learning procedures (Cheng, 2006). A high-quality education in schools contributes to developing scientific literacy and would be expected to predispose students to study the enabling courses at university (Zengele, \& Alemayehu, 2021). Despite the significant role of gender role self-concept for adolescents' competence and value-related beliefs and engagement regarding gendered domains, studies investigating gender differences in digital learning have so far concentrated on biological sex only, neglecting the role of gender role self-concept (Korlat et al., 2021). In general, some authors like Vekiri (2013) argued that sex differences in digital competence, attitudes, and motivation are becoming less prevalent, indicating a narrowing of the gender digital gap.

Researchers have made some helpful ideas for improving online learning. During COVID19, for example, ideas were made to improve undergraduate students' online learning by introducing an upper-level, project-based biochemistry laboratory program (Zewail-Foote, 2020). During the pandemic, students' coping strategies, negative and positive emotions were strongly linked and coexisted in online learning. Their coping strategies and stresses were strongly impacted by online resources, as well as retrospective and overall enjoyment (Maican \& Cocorada, 2021). Nonetheless, just a few prior researches have looked at the impact of educational level and personality on online learning.

\section{Statement of the Problem}

The flexibility online learning provides allows it to quickly gain popularity amongst students and teachers. The students make use of the internet every day for their personal use which is why educators decided to adopt its use into their learning as this will make learning more interesting to them and hereby motivation them to learn. Apart from this, students can also access learning content anywhere without having to be in physical contact with the students. Online learning further gained popularity globally during the ongoing COVID-19 pandemic which led to the closure of schools throughout the world. Educators had to adapt online learning on a full scale to ensure continuity of learning. To guarantee that their lives and those of their families are not jeopardized, children are not permitted to attend schools or educational institutions. The worldwide crisis created by the COVID-19 epidemic not only caused delays in traditional teaching and learning, but it also made teacher assignments more difficult as they had to adjust to new standards that necessitated teaching and learning process to be implemented online. Yu (2021) stated with the rampant pandemic of COVID-19, an increasing number of people are acquiring knowledge through online learning approaches. 
It is however important to carry out a study as to reimbursement of Google Classroom was and no previous studies known to the researcher has been conducted to examine this issue. Even though google classroom has being used by Unilorin students before the pandemic, it has never been used at this scale and magnitude, which is why this study will investigate the reimbursement of Google classroom by undergraduate students for learning vocational and entrepreneurship courses.

This study: (1) determined how undergraduate utilize Google Classroom for learning vocational and entrepreneurship courses; (2) investigated the influence of gender on undergraduate utilization of Google Classroom for learning vocational and entrepreneurship courses; (3) investigated the influence of academic level on undergraduate utilization of Google Classroom for learning vocational and entrepreneurship courses.

The following null hypotheses were tested in the study: (Ho1) There is no significant difference between male and female undergraduate utilization of google classroom for learning vocational and entrepreneurship courses; (Ho2) There is no significant difference among undergraduate students' utilization of Google Classroom for learning vocational and entrepreneurship courses based on their academic level.

\section{METHOD}

This study is a descriptive research of the quantitative type designed to examine the reimbursement of Google classroom by undergraduate students for learning vocational and entrepreneurship courses in University of llorin. The research employed the use of questionnaire to elicit information from respondents. Survey research employs questionnaire in this regard to gather necessary and meaningful information from the respondents. The population for this study comprised all students of University of Ilorin, Kwara state. The total number of students in University of llorin for the $2019 / 2020$ academic session is 45,885 . The target population comprised students who undertake a vocational and entrepreneur course in University of llorin, Nigeria. With a confidence level of $90 \%$ using Raosoft (2021) sample size calculator, sample size of 269 was recommended for this study. Simple random sampling technique were used to select 269 respondents across all levels in the university of llorin. Some of the population were purposively selected based on gender.

The research instrument for this study was a researcher-designed. The questionnaire consists of two sections that is, A and B. Section A consist of various questions on the respondents' demographic data that include faculty, gender, and level. Section B comprise of structured questions which is in scale response mode. The questionnaire was based on using four point acting scale. The formats of response are: Strongly Agree (SA), Agree, (A), Strongly Disagree (SD), and Disagree (D). The instrument was validated by four experts in educational technology and business education for face and content validity. Their comments observation and corrections were used to produce the final draft of the questionnaire.

Letter of introduction was taken to the Dean of each faculties to seek permission to conduct the study in their faculties. Ethical considerations were also considered as students were not be forced to attest to the questionnaire. Also, their data was only used for the benefits of this research as their anonymity was kept confidential. The respondents will volunteer to participate in the study and there will be no coercion of any sort. Also, the students were informed to freely partake or withdraw at any time without any repercussions. The data collected for the study was analysed using frequency counts, percentages, mean scores. All hypotheses were tested at 0.05 level of significance. Independent $t$ test was used in testing Hypothesis one and hypothesis two was tested with Analysis of Variance (ANOVA).

\section{RESULT AND DISCUSSION}

This section presents the analysis on the benefit of undergraduates' utilization of Google Classroom for learning vocational and entrepreneurship courses in University of Ilorin, Nigeria and the interpretation of the data through the analysis of the questionnaire items after the 
administration of the research instrument were done. The section presents the description of the research subjects, statistical analyses and results based on research questions and research hypotheses stated earlier in chapter one. The demographic information of the respondents and the results of the analyses are also presented both in tables and figures.

A total of 269 undergraduate students from University of Ilorin, llorin, Nigeria were sampled but responses from 250 respondents were properly filled and returned, comprising of 120 male students and 130 female students made up the sample for this study. The 269 respondents were given the research instrument with the items, and eventually were available and responses from 250 undergraduate students were properly filled and returned amounting to $92.9 \%$ response rate. The sample size for this research was sufficient and representative.

\section{Demographic Data}

The respondents' demographic data are presented in Tables 1-6.

Table 1. Respondents Data based on their Gender

\begin{tabular}{lccc}
\hline Gender & Frequency & Percent & Cumulative Percent \\
\hline Male & 120 & 48.0 & 48.0 \\
Female & 130 & 52.0 & 100.0 \\
Total & 250 & 100.0 & \\
\hline
\end{tabular}

Table 1 shows that male and the female respondents formed the study of the total sampled respondents with 120 (48.0\%) are male while 130 (52.0\%) females formed different percentage of the total sampled respondents respectively. This is also shown graphically in Figure 1.

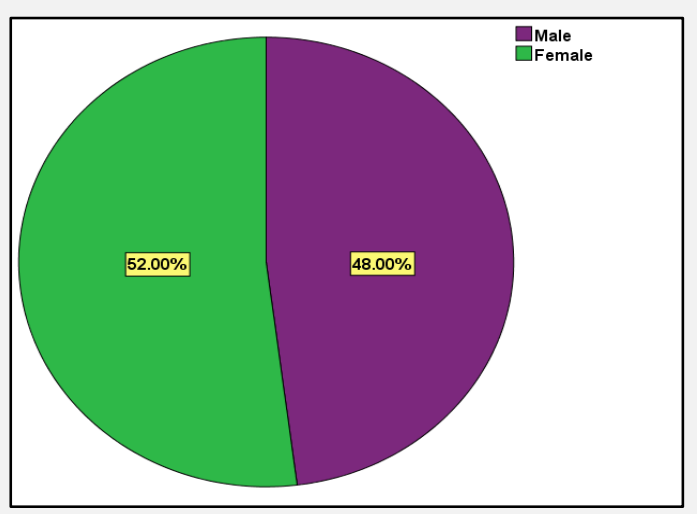

Figure 1. Graphical Illustration of Respondents' Gender

The pie chart (Figure 1) revealed that female undergraduate students were more than their female counterparts. Table 2 shows that respondents from first to fourth year in the university formed the study of the total sampled respondents with $19(7.6 \%)$ are in 100 level, $25(10.0 \%)$ are in 200 level, 85 (34.0\%) are in 300 level while 121 in 400 level formed a percentage 48.4\% of the total sampled respondents respectively. This is also shown graphically in Figure 2.

Table 2. Respondents Data based on their Academic Level

\begin{tabular}{cccc}
\hline Level & Frequency & Percentage & $\begin{array}{c}\text { Cumulative } \\
\text { Percent }\end{array}$ \\
\hline 100 & 19 & 7.6 & 7.6 \\
200 & 25 & 10.0 & 17.6 \\
300 & 85 & 34.0 & 51.6 \\
400 & 121 & 48.4 & 100.0 \\
\hline Total & 250 & 100.0 & \\
\hline
\end{tabular}




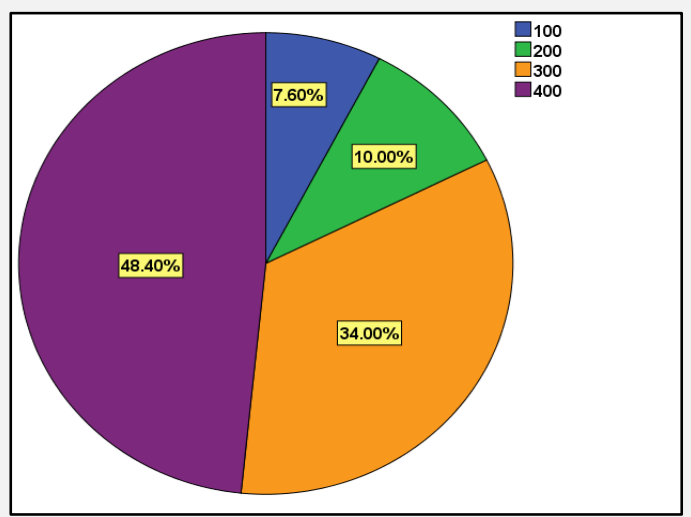

Figure 2. Graphical Illustration of Respondents' Academic Level

The chart in figure indicated that majority of the respondents were in their fourth year of their academic level, others are in first year, second year and third year respectively.

\section{RESULTS}

\section{Research Question One:}

What are the benefits of undergraduate utilizing google classroom for learning vocational and entrepreneurship courses?

The statistical tool of Mean was adopted to answer research question one as in Table 3. Table 3 revealed the results on the benefits of utilization of $\mathrm{GC}$ for learning vocational and entrepreneurship courses. These benefits among others revealed that students are not limited to what they are taught as they can explore other resources about the particular topic through online mediums, provides an interactive learning environment; can access missed work due to absence and also locate other resources they might need easily with mean scores of 3.54, 3.52 and 3.50 correspondingly. The grand mean scores of 3.47 launched that GC is very useful for learning vocational and entrepreneurship courses.

\section{Research Question Two}

What is the influence of gender on the benefit of undergraduates' utilization of google classroom for learning vocational and entrepreneur courses?

The difference between the influence of gender undergraduates' utilization of google classroom for learning vocational and entrepreneur courses was determined and mean difference was employed to establish this. The differences that exist between the influence of gender on the benefit in the undergraduates' utilization of google classroom for learning vocational and entrepreneur courses was as well determined as shown in Table 4. It indicated that the mean score on the male undergraduates' utilization of $\mathrm{CC}$ was 3.7 while the female undergraduates' utilization of $G C$ was 3.7. The mean gain of 0.00 deduced that gender had no influence on the benefits of undergraduates' utilization of google classroom for learning vocational and entrepreneur courses.

\section{Hypothesis One}

There is no significant difference between male and female undergraduate utilization of google classroom for learning vocational and entrepreneurship courses t-test was conducted to determine if there is any significant difference between male and female undergraduate utilization of google classroom for learning vocational and entrepreneurship courses. The result is shown in Table 5. 
Table 3. Undergraduate Utilization of GC for Vocational and Entrepreneurship Courses

\begin{tabular}{|c|c|c|c|}
\hline S/N & ITEMS & Mean & SD \\
\hline 1. & Google classroom provides an interactive learning environment & 3.52 & .603 \\
\hline 2. & $\begin{array}{l}\text { Google classroom helps provide exiting, autonomous and effective } \\
\text { teaching }\end{array}$ & 3.50 & .569 \\
\hline 3. & $\begin{array}{l}\text { Google classroom helps minimizes stationeries and materials cost } \\
\text { compared to traditional classroom }\end{array}$ & 3.48 & .589 \\
\hline 4. & $\begin{array}{l}\text { Lesser time and energy are spent by google classroom users } \\
\text { compared to the conventional classroom }\end{array}$ & 3.50 & .589 \\
\hline 5. & $\begin{array}{l}\text { Students are not limited to what they are taught as they can explore } \\
\text { other resources about the particular topic through online mediums. }\end{array}$ & 3.54 & .546 \\
\hline 6. & $\begin{array}{l}\text { Students don't longer have to worry about crashed computers or } \\
\text { hungry dogs as all files uploaded by teachers and students are stored } \\
\text { in a classroom folder on Google drive. }\end{array}$ & 3.32 & .655 \\
\hline 7. & $\begin{array}{l}\text { Google classroom helps students transition into other learning } \\
\text { management systems used in higher education. }\end{array}$ & 3.41 & .540 \\
\hline \multirow[t]{2}{*}{8.} & $\begin{array}{l}\text { Students can access missed work due to absence and also locate other } \\
\text { resources they might need easily }\end{array}$ & 3.50 & .554 \\
\hline & $\begin{array}{l}\text { Grand Mean on Benefits of Utilization of GC for Learning Vocational } \\
\text { and Entrepreneurship Courses }\end{array}$ & 3.47 & \\
\hline
\end{tabular}

Table 4. Difference on the Influence of GC based on Gender

\begin{tabular}{ccccc}
\hline Gender & $\mathrm{N}$ & Mean & Std. Dev & Mean Gain \\
\hline Male & 120 & 3.5 & .32 & \\
Female & 130 & 3.5 & .28 & \\
\hline Total & 250 & 3.5 & .30 & 0.00 \\
\hline
\end{tabular}

Table 5 indicates that $\mathrm{t}(248)=0.10, \mathrm{p}=0.92$. This means that the stated null hypothesis was not rejected. This was as a result of the $t$-value of 0.10 resulting in 0.92 significance value which was greater than 0.05 alpha value. By implication, the stated null hypothesis was established thus: There was no significant difference in the mean achievement score of male and female undergraduate in their utilization of google classroom for learning vocational and entrepreneurship courses in Table 5.

Table 5. Undergraduates' utilization of google classroom based on Gender

\begin{tabular}{llccccc}
\hline Gender & $\mathrm{N}$ & Mean & Std. Dev & Df & $\mathrm{T}$ & Sig. (2-tailed) \\
\hline Male & 120 & 3.47 & .32 & & & 0.102 \\
Female & 130 & 3.47 & .28 & 248 & 0.92 \\
\hline
\end{tabular}

\section{Hypothesis Two}

There is no significant difference among undergraduate students' utilization of google classroom for learning vocational and entrepreneurship courses based on their Academic level. The analysis for testing this hypothesis as shown in Table 6 was ANOVA statistical tool on students' utilization of GC based on their Level.

The analysis on significant difference among undergraduate students' utilization of google classroom for learning vocational and entrepreneurship courses based on their Academic level is displayed in Table 6. The null hypothesis was rejected as $F(3,249)=3.90$ and $p=0.009<0.05$. Since the $p$-value was less than the significance value of 0.05 , the hypothesis was rejected. Thus, there was no significant difference among undergraduate students' utilization of google classroom 
for learning vocational and entrepreneurship courses based on their Academic level. However, Sidak post-hoc was used to show the direction of the differences as shown in Table 7.

Table 6. ANOVA on Undergraduate' utilization of Google classroom by Academic Level

\begin{tabular}{llllll}
\hline Source & Type III Sum of Squares & Df & Mean Square & F & Sig. \\
\hline Corrected Model & $.993^{a}$ & 3 & .331 & 3.904 & .009 \\
Intercept & 1661.729 & 1 & 1661.729 & 19600.378 & .000 \\
Level & .993 & 3 & .331 & 3.904 & .009 \\
Error & 20.856 & 246 & .085 & & \\
Total & 3037.281 & 250 & & & \\
Corrected Total & 21.849 & 249 & & & \\
\hline a. R Squared $=.045$ (Adjusted R Squared $=.034)$ & &
\end{tabular}

Table 7. Sidak Posthoc on Direction of Differences on Undergraduates Utilization of Google Classroom

\begin{tabular}{|c|c|c|c|c|c|c|}
\hline \multirow[t]{2}{*}{ (I) Level } & \multirow[t]{2}{*}{ (J) Level } & \multirow{2}{*}{$\begin{array}{l}\text { Mean } \\
\text { Difference (l-J) }\end{array}$} & \multirow[t]{2}{*}{ Std. Error } & \multirow[t]{2}{*}{ Sig. } & \multicolumn{2}{|c|}{$95 \%$ Confidence Interval } \\
\hline & & & & & Lower Bound & Upper Bound \\
\hline & 200 & -.1387 & .08862 & .532 & -.3737 & .0964 \\
\hline \multirow[t]{3}{*}{100} & 300 & $-.2046^{*}$ & .07389 & .036 & -.4005 & -.0086 \\
\hline & 400 & $-.2340^{*}$ & .07185 & .008 & -.4246 & -.0434 \\
\hline & 100 & .1387 & .08862 & .532 & -.0964 & .3737 \\
\hline \multirow[t]{3}{*}{200} & 300 & -.0659 & .06625 & .902 & -.2416 & 1098 \\
\hline & 400 & -.0953 & .06397 & .588 & -.2650 & .0743 \\
\hline & 100 & $.2046^{*}$ & .07389 & .036 & .0086 & .4005 \\
\hline \multirow[t]{3}{*}{300} & 200 & .0659 & .06625 & .902 & -.1098 & .2416 \\
\hline & 400 & -.0294 & .04121 & .979 & -.1387 & .0799 \\
\hline & 100 & $.2340^{*}$ & .07185 & .008 & .0434 & .4246 \\
\hline \multirow[t]{2}{*}{400} & 200 & .0953 & .06397 & .588 & -.0743 & .2650 \\
\hline & 300 & .0294 & .04121 & .979 & -.0799 & .1387 \\
\hline
\end{tabular}

Based on observed means.

The error term is Mean Square (Error) $=.085$.

*. The mean difference is significant at the 0.05 level.

The post hoc test results in Table 7 on the differences on the benefit which utilization of GC for vocational and entrepreneurship courses have on undergraduate students based on their level was well reported. It indicated that there was significant difference between 100 level undergraduate students' and 300 level undergraduate students' utilization of google classroom for learning vocational and entrepreneurship courses. Also, there was significant difference between 100 level undergraduate students' and 400 level undergraduate students' utilization of google classroom for learning vocational and entrepreneurship courses. This is further justified with the chart in Figure 3. The chart indicated that undergraduate students' utilization of google classroom for learning vocational and entrepreneurship courses is directly proportional to their level. Students in their final year utilize GC for learning vocational and entrepreneurship courses the most, others followed suit in that order.

\section{Discussion}

This study investigated the benefits of undergraduates' utilization of google classroom in learning vocational and entrepreneurship courses in university of llorin, Nigeria. The findings established that Undergraduates also revealed using google classroom is very useful for learning vocational and entrepreneurship courses. This is in support of the findings of Huchthausen \& Droste, (2014) stated that the use of google classroom in vocational and entrepreneurship course help 
offers great opportunities in terms of improving the quality of education and reducing costs. Although the advent of rival programs such as Zoom, Blue Board, Edmodo, and others challenges Google Classroom's long-term usefulness with their specific features such as video conference calls, smart boards, and interactive boards, Google Classroom still has a lot to offer (Ochayi et al, 2021).

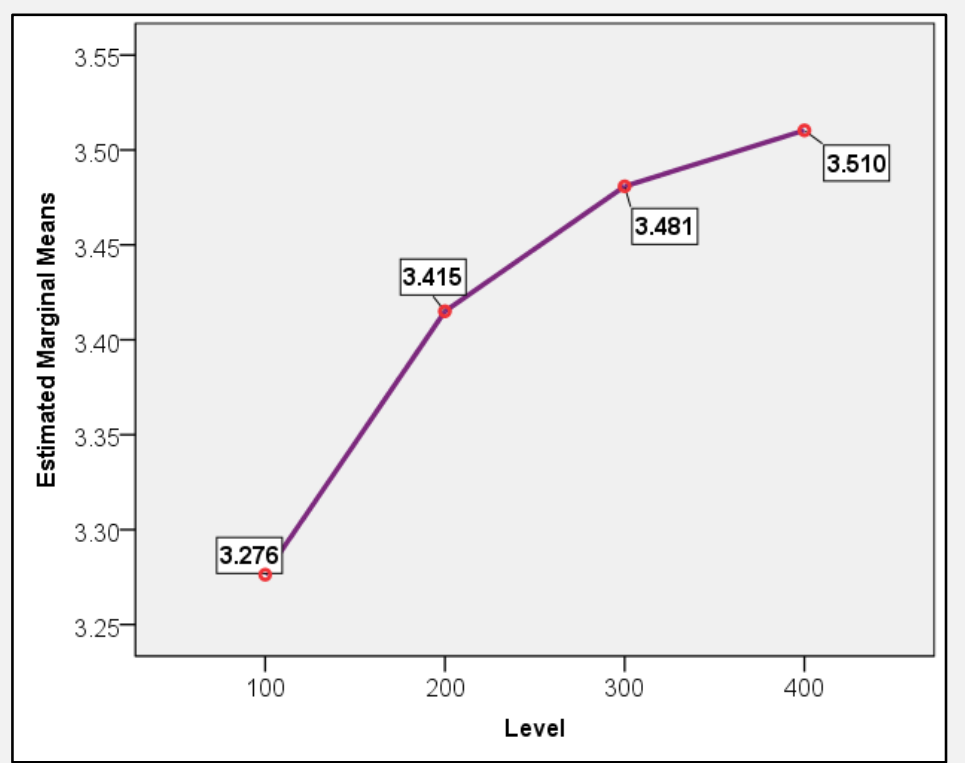

Figure 3. Estimated Marginal Mean on Utilization of GC by Level

GC remains one of the easiest to use, requiring no extra training from instructors or students, despite the current technological boom. Google Classroom is a great tool for teaching since it is effective, efficient, mobile, and easy to use. In their investigations, Huang et al., (2021) discovered a good attitude about the utilization of Google Classroom. However, educational institute management or administration has a big role to play in integrating technology in classrooms since they must finance or supervise the process and ultimately select how much technology will be used. Azhar \& lqbal (2018) investigated the role of administrators in the usage of technology in high schools and discovered that administrators had positive attitudes toward incorporating technology into the classroom.

The result from study also shows that gender had no influence on undergraduates' utilization of google classroom for learning vocational and entrepreneur courses. This goes in contrast with Oyelabo, (2018) who was of the opinion that there is a great difference between male and female in terms of use of a technology. Other results gotten from the study revealed that there was no significant difference between male and female undergraduate utilization of google classroom for learning vocational and entrepreneurship courses. This evidence is in backing of Gupta \& Pathania (2021) that there are no gender differences between male and female students in their Google classroom learning environments. Furthermore, Korlat et al. (2021) established that higher perceived teacher support, intrinsic value, and learning engagement among girls than boys, while no significant sex differences were found in competence beliefs regarding digital learning. Furthermore, their results indicated clear benefits of an androgynous gender role self-concept for all studied components of digital learning. Gender disparities in online learning results have been found to be inconsistent, if not contradictory. Richardson \& Woodley (2003) found that online female learners are more perseverant and engaged than men, but males had more consistent 
favorable attitudes regarding online learning (Nistor, 2013). Men can employ more learning techniques and have greater technical skills than females in online learning contexts (Alghamdi et al., 2020). Females have stronger self-regulation in online learning situations than males. Yu (2021) results might have neutralized gender biases in online learning, resulting in no significant gender disparities in online learning outcomes.

There was significance difference among undergraduate students' utilization of google classroom for learning vocational and entrepreneurship courses based on their Academic level in favour of the 400 level. This corroborates with the findings of $Y u$ (2021) who discovered that students did not find online learning to be the most effective instructional method since they rated professors and course material higher than online videos. The explanations might be that undergraduates were distracted by visual stimulus such as internet videos, or that they did not devote enough time to watching the videos to gain information (Evans, 2014). They may have been conversing with their buddies or searching the Internet for leisure. There were no significant gender disparities in online millennial learners' learning satisfaction based on academic level (Harvey et al., 2017).

\section{CONCLUSION}

The results gathered at the end of this research work shows that are several benefits of the utilization of google classroom by undergraduate students for learning vocational and entrepreneurship courses. When Google classroom is judiciously employed into the instructional procedures, aside the fact that it is going to boost learning activities, it will also help in saving costs as digital learning contents are cheaper compared to hard copies.

\section{ACKNOWLEDGEMNET}

We acknowledge the experts in the field of Educational technology across Nigeria that validated the instrument. We also express our thanks to reviewers and proofreaders, or technicians who help prepare the instrument. Lastly, we appreciate the efforts of undergraduate students which are respondents who assist in surveys.

\section{REFERENCES}

Ahmad, I. (2018). Digital learning process in the age of the industrial revolution 4. 0 era technology disruptions. Ministry of Research, Technology and Higher Education, 1-13

Ala, N. A. (2020). Effects of Animation-Package on Students' Performance in Vertebrate, Anatomy and Physiology in Colleges of Education, Bauchi State, Nigeria. Department of Educational Technology, Faculty of Education, University of Ilorin, Ilorin, Nigeria

Alghamdi, A., Karpinski, A. C., Lepp, A., \& Barkley, J. (2020). Online and face-to-face classroom multitasking and academic performance: Moderated mediation with self-efficacy for selfregulated learning and gender. Computers in Human Behavior, 102, 214-222. https://doi.org/10.1016/j.chb.2019.08.018

Atsumbe, B. N., Raymond, E., \& Duhu, E. B. (2012). Availability and Utilization of e-Learning Infrastructures in Federal University of technology, Minna. and Practice 3(13).

Awogbenle, A., \& Iwuamadi, K. (2010). Youth Unemploment: entrepreneuship intervention as an intervention mechanism, -. Afican Journal of Business and Management, 4(6), 831835.

Azhar, K., \& lqbal, N. (2018). Effectiveness of Google classroom: Teachers' perceptions. Prizren Social Science Journal, 2(2): 52-66. 
Cheng, K. (2006). A research study on students' level of acceptance in applying e-learning for business course: A case study on a Technical College in Taiwan. Journal of American Academy of Business, 8(2), 265-272.

Egbo, O. P., Okoyeuzu, C. R., Ifeanacho, I. C., \& Onwumere, J. U. (2011). Gender perception and attitude towards e-learning: A case of business students, University of Nigeria. International Journal of Computer 1(2), 135-148.

Evans, H. K. (2014). An experimental investigation of videotaped lectures in online courses. TechTrends, 58(3), 63-70.

Gupta, A. \& Pathania, P. (2021). To study the impact of Google Classroom as a platform of learning and collaboration at the teacher education level. Education and Information Technologies, 26, 843-857. https://doi.org/10.1007/s10639-020-10294-1

Hakim, A. B. (2016). Efektifitas Penggunaan E-Learning Moodle, Google Classroom Dan Edmodo. I-STATEMENT, 2(1), 135-151.

Harvey, H. L., Parahoo, S., \& Santally, M. (2017). Should gender differences be considered when assessing student satisfaction in the online learning environment for millennials? Higher Education Quarterly, 71(2), 141-158. https://doi.org/10.1111/hequ.12116

Hidayat, M. L. (2018). The modification of Ims quipperschool to improve senior high school students' concept mastery of biology subject, topic: human reproduction health. Journal of Educational Science and Technology (EST), 4 (1), 32-38.

Huang, T. H., Liu, F., Chen, L. C., \& Tsai, C. C. (2021). The acceptance and impact of Google Classroom integrating into a clinical pathology course for nursing students: A technology acceptance model approach. Plos one, 16(3), e0247819. https://doi.org/10.1371/journal.pone.0247819

Huchthausen, M., \& Droste, M. (2014). E-Learning: Vor- und Nachteile des onlinegestützten Lernens, ddm, Ausgabe 4, S. 82-83. http://digital-dental-magazin.de/wp-content/uploads/13_ELearning-Vor-und-Nachteile-des-onlinege.

Hwang, G. J., Lai, C. L., \& Wang, S. Y. (2018). Seamless flipped learning: a mobile technologyenhanced flipped classroom with effective learning strategies. Journal of Computers in Education, 2(4), 449- 473. https://doi.org/10.1007/s40692-015-0043-0

Korlat, S., Kollmayer, M., Holzer, J., Lüftenegger, M., Pelikan, E. R., Schober, B. \& Spiel, C. (2021). Gender Differences in Digital Learning During COVID-19: Competence Beliefs, Intrinsic Value, Learning Engagement, and Perceived Teacher Support. Frontiers in Psychology, 12(1), 637 776. https://doi.org/10.3389/fpsyg.2021.637776

Kumar, J., \& Bervell, B. (2019). Google Classroom for mobile learning in higher education: Modelling the initial perceptions of students. Education and Information Technologies, 24(2): 1793-1817. https://doi.org/10.1007/s10639-018-09858-z

Liaw, S. S., \& Huang, H. M. (2011). A study of investigating learners attitudes toward e-learning. 5th International Conference, 673.

Maican, M. A., \& Cocorada, E. (2021). Online foreign language learning in higher education and its correlates during the COVID-19 pandemic. Sustainability, 13(2), 781. https://doi.org/10.3390/su13020781 
Nasir, M. (2018). Improving the quality of vocational education in the era of industrial revolution 4.0. Kemenristek Higher Education.

Nistor, N. (2013). Stability of attitudes and participation in online university courses: Gender and location effects. Computers \& Education, 68, 284-292. https://doi.org/10.1016/j.compedu.2013.05.016

Nizal, I., Shaharanee, M. Jamil, J. M, Syamimi, S., \& Rodzi, M. (2018). The application of google classroom as a tool for teaching and learning. Journal of Telecommunication, Electronic and Computer Engineering, 8 (10), 8-11.

Ochayi, A. O, Obielodan, O. O., Onojah, A. A., Abdulrahman, M. R. \& Akpegi, P. (2021). Science Lecturers' Seeming Use of Google Classroom for Instruction. ASEAN Journal of Science and Engineering Education, 1(3), 142-150.

Olanipekun, W. D., Brimah, A. N., \& Rabiu, R. O. (2015). Entrepreneurial and vocational education revolution: A catalyst for sustainable development. Kuwait Chapter of Arabian Journal of Business and Management Review, 33(2587), 1-9.

Omoni, B. G., Ifeanyichukwu, N. G., \& Omoni, B. G. (2015). BUSINESS EDUCATION STUDENTS'UTILIZATION OF E-LEARNING IN ANAMBRA STATE TERTIARY INSTITUTIONS. International Journal of Scientific Research and Innovative Technology, 2(4), 16-25.

Onasanya, S. A. (2019). From the Slate Board to the Web: Paradigm Shift in Educational Resources Development. The One Hundred and Eighty Fifth in the Series of Inagural Lectures. University of llorin, Ilorin, Nigeria.

Onojah, A. O, Onojah, A. A. \& Onojah, A. A. (2020). Tech-20 the Perfect Epidemic to Covid-19 Pandemic and its Influence on Education: Offensive and Defensive Measures of New Media Technologies. Global Media Journal-Pakistan Edition, 13(1), 1-16.

Osalor, P. (2014). Vocational and Technical Education - A key to improving Nigeria's Development. Vanguard Newspaper, Tuesday, January 14th, 2014.

Otokiti, S. (2012). Entrepreneurship Curriculum for real economic development. Paper presented atthe2012entrepreneurshipDirectorsconferenceorganisedbytheCentrefor Entrepreneurship, Kwara State University, Malete.

Park, A. (2020). The tech that could be our best hope for fighting COVID-19-and future outbreaks. Retrieved from Time: https://time. com/5805622/coronaviruspandemictechnology.

Raosoft Inc. (2021). Sample size calculator. http://www.raosoft.com/samplesize.html

Richardson, J. T., \& Woodley, A. (2003). Another look at the role of age, gender and subject as predictors of academic attainment in higher education. Studies in Higher Education, 28(4), 475-493. https://doi.org/10.1080/0307507032000122305

Sewang, A. (2017). Keberterimaan Google Classroom sebagai alternatif Peningkatan Mutu di IAI DDI Polewali Mandar. JPPI (Jurnal Pendidikan Islam Pendekatan Interdisipliner), 1(1), 3546. 
Shittu, A. T., Gambari, A. I., Gimba, R. W., \& Hassan, A. A. (2016). Modeling Technology Preparedness as an Antecedent of Mathematic Pre-service Teachers' Self Efficacy, Perceived Usefulness and Intention Toward Use of Information Technology in Nigeria.

Soetan, A. K., Onojah, A. O., Alaka, T. B., \& Aderogba, A. J. (2020). Hearing Impaired Students' Self-Efficacy on The Utilization of Assistive Technology in Federal College of Education (Special) Oyo. International Journal for Cross-Disciplinary Subjects in Education, 11 (1), 4658 4666

Soni, S., Hafid, A., Hayami, R., Fatma, Y., Wenando, F. A., Al Amien, J., Fuad, E., Unik, M., Mukhtar, H. \& Hasanuddin, H. (2018). Optimalisasi penggunaan google classroom, e-learning \& blended learning sebagai media pembelajaran bagi guru dan siswa di smk negeri 1 bangkinang. Jurnal Pengabdian UntukMu NegeRI, 2(1), 17-20. https://doi.org/10.37859/jpumri.v2i1.361

Vekiri, I. (2013). Information science instruction and changes in girls' and boy's expectancy and value beliefs: in search of gender-equitable pedagogical practices. Computer Education 64, 104 115. https://doi.org/10.1016/j.compedu.2013.01.011

Wijaya, A. (2016, February). Analysis of factors affecting the use of Google Classroom to support lectures. In The 5th International Conference on Information Technology and Engineering Application (ICIBA2016). Bina Darma University.

Yu, Z. (2021). The effects of gender, educational level, and personality on online learning outcomes during the COVID-19 pandemic. International Journal of Educational Technology in Higher Education, 18, 14 (2021). https://doi.org/10.1186/s41239-021-00252-3

Zabadi, A. M., \& Al-Alawi, A. H. (2016). University Students' Attitudes towards E-Learning: University of Business \& Technology (UBT)-Saudi Arabia-Jeddah: A Case Study. International Journal of Business and Management 11(6), 286-295. http://dx.doi.org/10.5539/ijbm.v11n6p286

Zengele, A. G. \& Alemayehu, B. (2021). The Status of Secondary School Science Laboratory Activities for Quality Education in Case of Wolaita Zone, Southern Ethiopia. Journal of Education and Practice, 7(3), 1-11.

Zewail-Foote, M. (2020). Pivoting an upper-level, project-based biochemistry laboratory class to online learning during COVID-19: Enhancing research skills and using community outreach to engage undergraduate students. Journal of Chemical Education, 97(9), 2727-2732.

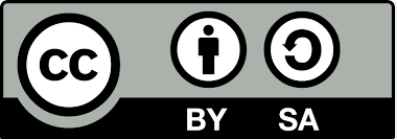
License. 